\title{
A Review of Semiotics in Advertising and Consumers' Attitude in the Indonesian Consumer Market
}

\section{Vidyarini Dwita}

Dept. of Management, Faculty of Economics, Universitas Negeri Padang, Padang, Indonesia

$\square$ (e-mail) vidyarini@fe.unp.ac.id

\begin{abstract}
The English language is increasingly used in non-English speaking countries. This paper focuses on attitudes towards the use of English advertising in Indonesia with the aim to analyze the effect of using English to advertise products on Indonesian consumers. This paper reviews the findings of literature in marketing research. The purpose of advertisers' use of English language is to appeal to consumers, to attract their attention and to stimulate them to learn more about advertised products. The findings proceed in the following manner that English as symbolic value is affecting the purchase intention because the use of English language in advertising is to improve the image of the product that associated with sophisticated and cosmopolitan products. The paper's analysis has implications for advertising for middle class consumers in Indonesia. The impact of English as prestigious language associated with high status, modernity and sophistication can bring an effect to consumers' attitudes to have good impressions about the products being advertised.
\end{abstract}

Keywords: semiotics in advertising, consumers' attitude, Indonesian consumer market, global advertising, and purchasing decisions

\section{Introduction}

The purpose of this paper is to apply a new insight about semiotics in advertising and its impacts on consumer behaviors. In particular, this paper focuses on the perception that the use of English or English-Indonesia language mix in advertisements message in the Indonesian market had the effect of consumers response to become aware and explain the content of advertising message.

This paper explains how the language on advertisement can affect consumer behavior like in Indonesia's complex language context. Moreover, the analysis clarifies the reasons for consumers' attitude to recognize the purpose of symbolic use of English in Indonesian advertising and the response of consumers toward marketing communication that use English which is a foreign language to consumers. There has been lack of rigorously literal studies on the semiotics uses of English in advertising in Indonesia, in spite of the fact that to some extent limited studies do exist. As such, this paper aims to discuss the gap in the literature and clarify a part of the symbolic use of English bring in advertising in Indonesia for middle-class consumers.

In addition, English has a high status in modern society that having considerable advantages in economics to people who have comparatively better ability (Lauder, 2008). A great significance to consider that maybe an exception for Indonesian that English proficiency is very low as language to use for communication (Kam, 2002). In fact, at a recent time English become the main source of loaned words in Indonesia that is related with something modern (Lauder, 2008). For the members of middle class, English symbolized prestigious language that associated with higher education, wealth, upper class and so forth. Moreover, English becomes high symbolic value in Indonesia despite the mastery and ability to use English for communication is very limited among Indonesian society. Furthermore, the growing of middle class in Indonesia makes this country a potential market for global companies. Advertising for products of this kind of consumer markets need to be modified with the social attitudes of Indonesian with respect to linguistic and cultural content. However, the particular kind such as concepts and the use of language of this content has not been studied 
rigorously only a small number of studies have examined the impact of marketing communication like advertising on Indonesian consumers.

\section{Global advertising}

The evolution of global advertising began in the $19^{\text {th }}$ century and had changed so much that it is important to build brand awareness among consumers through promotion (Jain \& Roy, 2012). From then till now, advertising has become the major part of business activities that need to develop into generously specially designed for marketing communication. The global advertising state is being complex because global markets is widely recognized as is the need to adapt for various target markets in foreign countries within it (Bulmer and Buchanan-Oliver, 2006).

In the time, standardization and adaptation are mattering much in global marketing strategies because of the differences of cultural environment of the target markets may impacts to marketing activities such as products, price, distribution and promotion. De Mooij (2010) finds something like a convergent state, standardized marketing and advertising has become polemical over the past few decades, in spite of the fact that the action of standardizing and products has benefits related to the result of increasing in production output and more efficient research and growth. However, standardization in advertising is not always can be exist or advisable because of differences in consumer's need and wants in different kind of markets.

The use of English also makes it easy for the global cultural environment and is widely found around the world (Crystal, 2003). This also includes the use of English in the world where the largest population does not speak English and can be used as a way for global companies to reach target markets outside the country of origin (Planken, Meurs, \& Radlinska, 2010).

For this reason, standardized advertising in target markets can be adapted by using translated copy of the original advertisements into local language. Moreover, local copywriters have to be aware of the use of English language that can be understood by people in target markets. Many consumers in non-English target market do not understand the meaning of the words in ads (De Mooij, 2003).

\section{Consumer Behaviors and Attitudes}

Distinctive the culture, including language can relating to influence advertising in various markets (Doole \& Lowe, 2008). Creating global advertising is not simple to elaborate, since the use the characteristic of misappropriate of perception of words in a local language to become altered or modified of brand perception, sales, and market share of the brand in question. Inappreciable of global marketing strategy in global advertising media may affect generally on marketing communication in the way to impress about company's image and consumer response (Jain \& Roy, 2012).

Studying culture can be considered by global marketer to bring out the capabilities of global communication that does not rely on all consumers present the same view of products and the experience in the same character of purchasing behavior. Having a specified kind of challenged for global advertising for global brands to create advertising account that suitable for dissimilarity relating to different culture. Advertising is a part of marketing communication that able to persuade and exploit media that necessary part of the global companies to advance clearly perceptible impression about products that is likely brought to mind by consumers. In this, however, cultural differences can be something that constraints to required awareness in the parts of global marketing.

In the majority of instances the use of English in non-English speaking conditions do not use full sentences, only words and phrases. This because consumers who view the ads probably are not look at carefully so as to understand the meaning of message but may react favorably to the symbolic material of the English(Cheshire \& Moser 1994). Moreover, the purpose of the use of local language added with English is used many times to raise the act of comprehending (Loveday 2008). Hassan 
and Katsanis (1991) note this as well and discuss the considerable challenge for consumer marketing in global markets that involves dealing with segmented market across cultures.

De Mooij and Hofstede (2010) present a model for effective advertising intended to address this issue that incorporates an understanding of the cultural values of consumers. This model implies strategy that centers on individual consumer who is the see as having unique social and mental process. The model is based on the idea that each individual is an autonomous entity with attributes, qualities and process that give rise to behavior as well as personality factors that come from differences in traits, abilities, motives and values.

Additionally, De Mooij (2005) discuss about systematic series of social development that express to influence consumer behavior to buy something and include motivation, needs, emotions, drive and group's greatest resource. Moreover, cultural differences may also affect to behavior which the influenced by society may impact to purchasing decision where informal communication in society may serve as source for information is obtained. For instance, how people in collectivist culture may access information from social networking while those in individualistic cultures may count on the mass media.

De Mooij and Hofstede (2010) discuss how the mental process bring into to how people see, think, use language, and learn and communicate are essential quality of an internal psychological system that develops through socialization in a given environment and illustrate by example in the cultural capacity of consumer decision making and behavior. A different form of culture in process of social inferring mention that the psychology of culture to come into being a confusion factor that impacts consumer behavior ( Norenzayan, Choi, \& Nisbett, 2002).

The literary works present that consumer attitudes, perceptions and beliefs are significant impact to their decisions to purchase products. Their intentions and emotional perceptions are influenced by knowledge gained through communication that they process by

transmitted through language and images of advertising. In a particular, the material world of advertising is desperate for attention because of attitude toward product can be contraction either a positive or negative mood that will influence the act of preferring in opposition or confirming about the products.

\section{Semiotics in Advertising}

The use of English in advertisements in non-English speaking countries is increasing in order to influence consumers' perception of the products being promoted and influence purchasing decisions. While, the use of English is also important to give a certain impression about the product or service (Krishna \& Ahluwalia, 2008) and also attract consumers' attention about the advertised product (Garcia-Yeste, 2013). Moreover, the use of English in marketing massage also shows the ability to arouse consumers' sense about product being advertised (Puntoni, Langhe \& Osselaer,2009).

In many part of the world, the use of English in non-English speaking target markets has been used as symbolic value where the language is not used for communication instead to draw consumers' attention about products being advertised that will affect the purchase decision. The consumers not expected to understand the intent of message in advertising but more to respond to the awareness of English language as symbols (Haarmann, 1986). Also found the fact that many consumers in non-English speaking markets do not understand the meaning of English words used in advertising (De Mooij,2003). However, there is a standard in the use of English on ads that should be considered if there is an urgent to make standardization of ads for various targets markets in the worldwide (De Mooij, 2010).

The advertising language have tendency toward cultural weight without regard for consumers will understand the intent of message in advertising that used English language on ads and in spite of that consumers no need to comprehend the actual meaning of the words. However, the use of English 
slogans considered together with text in local language or mixing with the language of target markets can be uncertain for advertisers because it will be not easily to delight their message in new forms. For this purpose, large number of global marketer select to choose English for their ads as a point to globalize and customize their product (Bhatia \& Ritchie, 2013).

The use of English on ads bring benefits to create a profitable brand image and provide high value to consider if company want to become of global markets. Nevertheless, the reason is because of the symbolic value of English terms and slogans, not relating to the words or vocabulary, that is many times persuading to potential consumers, it is breakthrough great significance for advertisers to grasp the meaning of language being used in the target markets and have more knowledge the secondary meaning and accepted usage of the loan words and terms in code switching language.

The principles of semiotics were developed by Ferdinand de Saussure (Crystal,1997), was interested in analysis the meaning of symbols or images as signs in social context. The meaning of a sign, in this purpose, associated with symbol that is commonly to identify the language or culture interest. The study of semiotics focus on explaining how signs carry out or bring the meaning in context. Babbie (2010) notes that semiotics relates to common interest of state being associated of signs as they understood by society of a culture of interest.

Semiotics are frequently being used in marketing with purpose to encourage consumers to state in mind of brand images. Whole persuasive signs such as brand names, logos and slogans are used to attract consumers' attention to relate with everything associated with products or services (Beasley \& Danesi 2002). It has been found that semiotic is the starting point of the communication process that directs the decision to purchase of goods and services on advertising (Bianchi 2011). For this reason, advertising is often used by companies as part of marketing communication to interpret messages by semiotics about the value of products. (Epure, Eisenstat \& Dinu 2014).

In non-English speaking countries like Indonesia, English language has high symbolic value that attracts people to become part of the global consumers culture. For this reason, then an advertising copywriter must have an insight about how to attract target market like in Indonesia by creating English language in ads that easily understood by Indonesian consumers. The language situation in Indonesia is complex and involves multiple language, not just Indonesian and English but also local languages in many part of regions in Indonesia. The use of English in advertising have to focused on the effect of and status it can give to a product being advertised.

\section{Conclusions}

Cultural differences have considerable effect on people's attitude towards advertising messages in several markets. The use local or mixed language in advertising, however, may be arranged to divert consumers' attention without bring out around them of a product's value (Jansson-Boyd, 2010). On the other hand, it may give permission for consumers to understand the information presented. The use of foreign language like English in advertising, is part of a marketing communications strategy to attract consumer's interest of a product. Advertisers often use English in non-English speaking target markets like in Indonesia as a way to create having knowledge about the product and take advantage on the state of being associated of the English language. The intend of advertiser use of English language to be pleasing consumers, by stimulating interest and attract their attention to learn more about advertised products. The use of English language in advertising is to improve the image of product that associated with sophisticate and with words products.

The paper findings have implications for marketing research related to advertising for middle class consumers specifically in Indonesia. Standardized or adapted advertisement can be used by global marketing communication strategy to gain full benefits by using English language in Indonesian ads. English as prestigious language, which is associated with sophisticated and high quality, affects consumers behaviors like their beliefs, feelings, attitude and intentions to have good impressions about product being advertised. 


\section{References}

Babbie, E. R. (2010). The Practice of Social Research. 12th ed. Belmont, Calif: Wadsworth Cengage.

Beasley, R., \& Danesi, M. (2002). Persuasive Signs: The Semiotics of Advertising. New York: Mouton de Gruyter.

Bhatia, T. K., \& Ritchie, W. C. (2013). The Handbook of Bilingualism and Multilingualism. 2nd ed. Chichester, West Sussex, UK: Wiley-Blackwell.

Bulmer, S., \& Buchanan-Oliver, M. (2006). Advertising across cultures: interpretations of visually complex advertising. Journal of Current Issues $\mathcal{E}$ Research in Advertising, 28(1), 57-71. doi:10.1080/10641734.2006.10505191.

Cheshire, J., \& Moser, L. M. (1994). English as a cultural symbol: The case of advertisements in French-speaking Switzerland. Journal of Multilingual \& Multicultural Development, 15(6), 451-469.

Crystal, D. (1997). The Cambridge Encyclopedia of Language. 2nd ed. Cambridge: Cambridge University Press.

Crystal, D. (2003). English as a Global Language. $2^{\text {nd }}$ ed. Cambridge: Cambridge University Press.

De Mooij, M. (2003). Covergence and divergence in consumer behavior implication to global advertising. International Journal of Advertising, 22, 183 - 202.

De Mooij, M. (2005). Global marketing and advertising understanding cultural paradoxes. $2^{\text {nd }}$ ed. United States: SAGE.

De Mooij, M. (2010). Consumer Behavior and Culture: Consequences for Global Marketing and Advertising. $2^{\text {nd }}$ ed. Thousand Oaks: SAGE Publications.

De Mooij, M., \& Hofstede, G. (2010). The Hofstede model: Applications to global branding and advertising strategy and research. International Journal of Advertising, 29(1), 85-110.

Doole, I., \& Lowe, R. (2008). International Marketing Strategy Analysis, Development and Implementation. $5^{\text {th }}$ ed. London: Cengage Learning EMEA.

Epure, M., Eisenstat, E., \& Dinu, C. (2014). Semiotics and persuasion in marketing communication. Linguistic and Philosophical Investigations, 592.

Garcia-Yeste, M. (2013). The presence and roles of English in Swedish print advertising: An exploratory study. Nordic Journal of English Studies, 1, 65.

Haarmann, H. (1986). Verbal strategies in Japanese fashion magazines-A study in impersonal bilingualism and ethno-symbolism. International Journal of the Sociology of Language, 58, 107-121.

Hassan, S. S., \& Katsanis, L. P. (1991). Identification of global consumer segments: A behavioral framework. Journal of International Consumer Marketing, 3(2), 11-28.

Jain, V., \& Roy, S. (2012). The emerging trends in global advertising. Media Asia, 39(4), 175-182.

Jansson-Boyd, C. V. (2010). Consumer Psychology. Maidenhead: Open University Press, c2010.

Kam, H. W. (2002). English language teaching in East Asia today: An overview. Asia Pacific Journal of Education, 22(2), 1-22.

Krishna, A., \& Ahluwalia, R. (2008). Language choice in advertising to bilinguals: Asymmetric effects for multinationals versus local firms. Journal of Consumer Research, 35(4), 692-705.

Lauder, A. (2008). The status and function of English in Indonesia: A review of key factors. Makara, Sosial Humaniora, 12(1), 9-20.

Loveday, L. J. (2008). Creating a mock-western identity through English in Japanese ads: A study of occidentalist invocations. Journal of Creative Communications, 3(2), 123-153.

Norenzayan, A., Choi, I., \& Nisbett, R. E. (2002). Cultural similarities and differences in social inference: Evidence from behavioral predictions and lay theories of behavior. Personality $\mathcal{E}$ Social Psychology Bulletin, 1, 109.

Planken, B., Meurs, F. V., \& Radlinska, A. (2010). The effects of the use of English in Polish product advertisements: Implications for English for business purposes. English for Specific Purposes, 29(4), 225-242. doi: 10.1016/j.esp.2010.06.003

Puntoni, S., Langhe, B. D., \& Osselaer, S. M. J. V. (2009). Bilingualism and the emotional intensity of advertising language. Journal of Consumer Research, 6, 1012. 